\title{
HRY FRANKA WOLLMANA NA SCÉNE SLOVENSKÉHO NÁRODNÉHO DIVADLA V DVADSIATYCH ROKOCH 20. STOROČIA
}

\author{
ANNA ZELENKOVÁ \\ Slovanský ústav Akadémie vied Českej republiky, v. v. i., Praha
}

\begin{abstract}
Abstrakt: Štúdia analyzuje hry Franka Wollmana na scéne Slovenského národného divadla v dvadsiatych rokoch 20. storočia. Autor pôsobil ako český slavista na vznikajúcej Filozofickej fakulte Univerzity Komenského v Bratislave. V začiatkoch svojej kariéry sa profiloval aj ako „československy cítiaci“ dramatik, ktorý v knižne vydanej dráme Bohokrál (1921) zachytil osobnost' Alexandra Vel'kého a v inscenovanej historickej tragédii Rastislav (1922) prostredníctvom vel'komoravskej látky idey česko-slovenskej vzájomnosti. Najväčší ohlas dosiahla jeho „ludská groteska a politická utópia“ Člun na moři (1924), konfrontujúca protikladné ludské typy. Wollmanove drámy celkovo exponovali vel'ké sociálne konflikty a svojím dôrazom na morálny étos mali skôr knižný charakter. Expresionistické prvky spájali s odkazom klasickej realistickej drámy. Aj ked’ sa po prvom uvedení nestali súčastou kmeňového repertoáru SND, zostali svedectvom nielen umeleckého formovania autora, ale aj dramaturgie SND.
\end{abstract}

Klúčové slová: Frank Wollman, Bohokrál, Rastislav, Člun na moři, česko-slovenské vztahy, začiatky SND

Frank Wollman (1889 - 1969) je známy najmä v slavistickom a komparatistickom kontexte, v ktorom sa vyprofiloval ako štrukturálne orientovaný literárny vedec pôsobiaci na Filozofickej fakulte Univerzity Komenského v Bratislave a na Filozofickej fakulte Masarykovej univerzity v Brne. Pri celkovej charakteristike tejto mnohostrannej osobnosti sa aj v súčasnosti neustále obchádza integrálna súčast̉ jeho práce - činnost' umelecká, najmä dramatická, ktorej sa doteraz nevenovala takmer žiadna interpretačná pozornost'. Zmienky o nej nachádzame najmä v príležitostných a jubilejných článkoch a recenziách, ktoré však dnešná teatrológia opomína, takže Wollmanovo meno zmizlo zo širšieho spoločenského povedomia. Dráma pre neho existovala nielen ako predmet vedeckého výskumu, ale aj ako forma vlastného umeleckého vyjadrenia. ${ }^{1}$ Autorove profesné začiatky i životné osudy boli ovplyvnené rokmi prežitými na Slovensku, patril k mladej vedeckej generácii, ktorá po roku 1918 spojila svoju kariéru s novo vybudovanou Univerzitou Komenského. Ale na začiatku dvadsiatych rokov sa výrazne prejavila aj umelecká stránka jeho osobnosti - pre túto avantgardnú generáciu bol charakteristický vnútorný svár vedy a umeleckých ambícií. ${ }^{2}$ Bol tiež autorom básní či poviedok a nádejným divadelným autorom, ktorého hry sa hrali na scéne SND v Bratislave aj v divadlách v Prahe, Brne a Plzni. ${ }^{3}$ Ale jeho divadelná

\footnotetext{
${ }^{1}$ OSOLSOBĚ, I. Danost tvarově intencionální aneb wollmanovské opáčko. In Program Státního divadla v Brně, 1968, roč. 39, máj, s. 13.

${ }^{2} \mathrm{~F}$. Wollman popri básnickej zbierke Bludný kámen publikoval v roku 1918 niekol'ko básní aj v Kněhyni. Zarad’uje sa medzi spoluzakladatel’ov umeleckého združenia Koliba založeného v roku 1914.

${ }^{3}$ Tituly Wollmanových realizovaných i nerealizovaných divadelných hier pozri ZELENKOVÁ, A. Bibliografia Franka Wollmana. In Slavista Frank Wollman v kontexte literatúry a folklóru I. (Eds. H. Hlôšková A. Zelenková). Bratislava - Brno : Ústav etnológie SAV : Slavistická společnost Franka Wollmana v Brne, 2006, s. 19 - 21, 48 - 49. V bibliografii sú zmapované aj informácie o premiérach a ohlasoch či recenziách v Čechách a na Slovensku.
} 
tvorba nebola doteraz vôbec spracovaná, iba v niektorých slovníkových heslách sa uvádzajú tituly Wollmanových hier a najviac sa (aj ked’ iba stručne) vyzdvihuje jeho podiel na založení Divadelnej fakulty v Brne ${ }^{4}$, kde bol v rokoch 1948 - 1949/1950 jej prvým dekanom. Pri návratoch k osobnosti Franka Wollmana ako dramatika však musíme skonštatovat', že väčšia čast̉ jeho dramatickej tvorby zostala ukrytá v jeho osobnej, doteraz nesprístupnenej rukopisnej pozostalosti. ${ }^{5}$

Wollman patril na Slovensku ku komunite Čechov, ktorí síce „cítili československy“, ale v otázke jazykovej jednoty prejavovali vel'ké pochopenie pre slovenské záležitosti, čo svedčilo o určitej miere sociálnej adaptácie českej minority. ${ }^{6} \mathrm{~V}$ bratislavskom prostredí sa aktívne zapájal do slovenského kultúrneho a umeleckého života. Hana Gregorová vo svojich Spomienkach (1979) uviedla, že iniciatíva založit Umeleckú besedu slovenskú vyšla v roku 1921 zo spoločenského okruhu literárneho salónu v ich bratislavskom dome. Je nesporné, že Wollmanovo členstvo v Literárnom odbore Umeleckej besedy slovenskej, ale aj priatel'stvo s manželmi Gregorovcami ${ }^{7}$ prispelo k jeho užšej integrácii do slovenského kultúrneho života, čo mu otváralo aj cestu na scénu SND. To sa formovalo v situácii, ked’ neexistoval pôvodný slovenský profesionálny slovenský súbor a ani rozsiahlejšia dramatická literatúra so širším diváckym zázemím. Na začiatku dvadsiatych rokov 20. storočia chýbala, ako uvádza divadelný historik Ladislav Lajcha, „systematická dramaturgia, ktorá by otvárala perspektívu činohry“ ${ }^{8}$ Koncepcia SND a jeho dramaturgia boli v tomto období rozvíjané najmä ako kultúrotvorný výraz novej československej štátnosti. ${ }^{9}$ Vytváral sa tak priestor aj pre českých umelcov žijúcich na Slovensku a pre historické látky zobrazujúce spoločné dejiny oboch národov.

Prvou hrou Franka Wollmana bola filozoficko-lyrická tragédia Bohokrál $(1921)^{10}$, ktorá zachytila historickú osobnost’ Alexandra Vel'kého a odrážala problematický vztah západného individualizmu a východného kolektivizmu. Už v tomto dramatickom pokuse sa objavila pre autora charakteristická téma súvisiaca s aktuálnymi problémami doby - s otázkou zapojenia vedúcej osobnosti do vyššieho celku, ktorému by mala slúžit’ v prospech všeobecného blaha. „(...) řeší poměr osobnosti k celku a řádu, tragiku bohokrálství a jedinečnosti. Je v něm kus agonie doby “11, napísal de-

${ }^{4}$ Zákon číslo 168/1947 Sb. o založení Janáčkovej akadémie múzických umení v Brne s odborom dramatickým a hudobným. Podl’a tohto zákona bolo štúdium na JAMU zrovnoprávnené s ostatnými vysokoškolskými štúdiami.

${ }^{5}$ Umelecká tvorba F. Wollmana je doteraz nespracovaná a väčšinou verejnosti neznáma. Nachádza sa v jeho osobnej pozostalosti, ktorá je uložená u autorky štúdie A. Zelenkovej.

${ }^{6}$ K danej problematike pozri bližšie napr. LUTHER, D. Česi v Bratislave 1919 - 1945: adaptácia a marginalizácia. In Slovenský národopis, 2013, roč. 61, č. 4, s. 368 - 378; RYCHLÍK, J. Češi na Slovensku v letech 1918 - 1938. In Česi na Slovensku. (Ed. H. Zelinová). Martin : Slovenské národné múzeum, 2000, s. 5 - 17; MLYNÁRIK, J. Českí profesori na Slovensku I. Českí profesori a ich slovenskí žiaci na Univerzite Komenského v rokoch 1919 - 1949. Praha : Danubius, 1994.

${ }^{7}$ O vzt’ahu F. Wollmana a J. G. Tajovského pozri bližšie ZELENKOVÁ, A. Frank Wollman a Jozef Gregor Tajovský - dve osobnosti česko-slovenského kontextu v medzivojnovom období. In Středoevropský areál ve vnitřních souvislostech (česko-slovensko-mad’arské reflexe). (Eds. I. Pospíšil - J. Šaur). Brno : Masarykova univerzita, 2010, s. $131-142$.

${ }^{8}$ LAJCHA, L. Prvých dvanást’ sezón. Predpoklady vzniku činohry SND: 1920 - 1932. In Slovenské divadlo, 1994 , roč. 42 , č. 3, s. 247.

${ }^{9}$ Tamže, s. 246.

${ }^{10}$ WOLLMAN, F. Bohokrál. Praha : Veraikon, 1921.

${ }^{11}$ F. Wollman v liste E. Pacovskému z 8. 3. 1920, ktorý je uložený v LA PNP v Prahe, fond Emil Pacovský. 
butujúci Wollman v marci 1920 do Prahy maliarovi a vydavatelovi Veraikonu Emilovi Pacovskému. ${ }^{12} \mathrm{~V}$ dráme sa vyrovnával s nietzscheizmom a pod bohokrál'ovstvom chápal predstavu novej zbožnosti a novej sociálnej viery, ku ktorej Alexander Vel'ký márne hl'adal cestu a zahynul preto, že sa nedokázal zbavit’ svojich vypätých citov a subjektívneho ega.

Bohokrál vyšiel iba knižne a nedostal sa na divadelnú scénu, ale druhá dráma, hra v piatich dejstvách Rastislav ${ }^{13}$, ktorá bola uvedená na scéne SND v Bratislave 17. 3. 1922 (réžia Milan Svoboda), získala štátnu dramatickú cenu a vyvolala aj väčší záujem divadelných kritikov. ${ }^{14}$ Rukopis dokončil v auguste 1920 a dedikoval ho literárnemu kritikovi Jaroslavovi Vlčkovi (1860 - 1930), ako výraz úcty k jeho literárnohistorickému dielu symbolizujúcemu korene a perspektívy česko-slovenskej kultúrnej spolupráce. Dokladajú to aj Wollmanove slová v liste slavistovi Jiřímu Polívkovi: „Dunaj, pádící k východu, připomenul mi můj starý sen, Alexandra Vel[ikého], a na jaře Děvín, pomník kolektivní slovanské tvorby, probudil mne k Rastislavu. "15

Po roku 1918 dochádza so vznikom Československej republiky k oficiálnej kanonizácii vel'komoravskej tematiky. ${ }^{16}$ Dobovú oblúbenost tejto látky využil aj Wollman, ktorý sa v Rastislavovi zameral najmä na dramatický zápas o moc medzi Rastislavom a Svätoplukom. Na osudoch klúčových postáv sa pokúsil zachytił tažiskové idey, pričom tradičnú historickú tému obohatil o subjektívne prvky. Postavy panovníkov sa snažil bližšie približit’ aj prostredníctvom vyhranených l'udských konfliktov, akými sú motívy zrady, lásky, vášne alebo túžby po moci. Dej je situovaný do rokov 869 až 879 a zobrazuje zápas vel'komoravského panovníka s Nemcami pod Devínom. Rastislav je v hre exponovaný ako odvážny stratég, politik a organizátor vel'kej ríše. Svoju koncepciu slobodného a zjednoteného národa realizoval prijatím krestanstva založeného na vlastnej slovanskej liturgii. Jeho tragický pád má metaforický a hrdinský podtext - vojvodca, ktorý vidí do budúcnosti, umiera zradou svojho synovca Svätopluka ako slepec v temnote. Rastislav stelesňuje integračnú ideu Slovanov na náboženskom (krestanstvo) a národnostnom princípe (antinemecký postoj). Je exponovaný nehistoricky, profilovaný titansky a nadludsky, ale trpí najmä problémami človeka na začiatku 20. storočia. Prostredníctvom neho autor vysvetl'oval vznik, tragické peripetie a zánik Vel'komoravskej ríše, ktorá sa po výbojoch franského západu a avarskej expanzie stahovala na východ, pod slovenské hory, pod Kriváň, t. j. na posvätnú pôdu predkov. Motívy slovenských hôr a starobylej Nitry tu akoby symbolizovali vlastný životný príbeh dramatika, ktorý zo „západu“ (z Prahy) prišiel na „východ“ (na Slovensko), aby tu hl'adal existenčnú istotu a vnútorný pokoj v období kultúrneho chaosu a všeobecnej krízy hodnôt.

${ }^{12} \mathrm{~V}$ záujme autenticity a priblíženia poetiky Wollmanovho jazyka ponechávame citáty z jeho textov a korešpondencie $\mathrm{v}$ pôvodnom českom jazyku.

${ }^{13}$ WOLLMAN, F. Rastislav. Košice : Slovenský knihtisk, 1922.

${ }^{14}$ Súpis jednotlivých divadelných referátov pozri ZELENKOVÁ, A. Bibliografia Franka Wollmana. In Slavista Frank Wollman v kontexte literatúry a folklóru I.

${ }^{15}$ F. Wollman v liste J. Polívkovi z 5. 11. 1920, ktorý je uložený v LA PNP v Prahe, fond Jiří Polívka.

${ }^{16}$ Vel'komoravská látka F. Wollmana bola v českom prostredí analyzovaná v štúdii ZELENKOVÁ, A. Vel'komravská látka v dramatickej tvorbe Franka Wollmana. In Myšlenkové toposy literatury v česko-slovenských souvislostech (minulost a současnost). (Eds. I. Pospíšil - A. Zelenková). Brno : Tribun EU, 2014, s. 205 217. 
„(...) cítím sám, že začínám dramaticky plně vidět a tvořit“17, napísal Wollman, ktorý sa počas príprav na javiskové uvedenie Rastislava skontaktoval aj s Bohumilom Mathesiom, pôsobiacim v Bratislave z poverenia Ministerstva školstva a národnej osvety ako tajomník Družstva SND. Čechoslovakisticky orientovanému Mathesiovi idea hry vyhovovala, preto už v októbri 1920 súhlasil s inscenáciou na scéne SND. Uvedenie hry však ovplyvnili nielen problematické vnútorné pomery v divadle, ktorými boli koncepčné spory Mathesia s riaditel’om Bedřichom Jeřábkom pre právomoc v otázkach hospodárskej prevádzky a dramaturgického plánu, ale aj rozhodovanie sa medzi češtinou a slovenčinou ako javiskovou rečou hry. SND pocitovalo nedostatok pôvodných hier uvádzaných v slovenskom jazyku, ktoré by prilákali domáce obecenstvo, a preto sa uvažovalo o preklade do slovenčiny. Autor váhal, či ponechat' Rastisla$v a \mathrm{v}$ češtine, alebo zvolit poslovenčenie. Z korešpondencie vieme, že na začiatku síce nesúhlasil s prekladom, ale postupne pod vplyvom Vavra Šrobára, ktorý si uvedomil prítažlivost' historickej témy rozvíjanej - povedané slovami Wollmana - „už v kulturněhistorickém prostředí slovenském“18, ustúpil. Celkovo však nepodporoval navrhnutú slovakizáciu. Jedným z dôvodov, prečo nakoniec zmenil názor, mohla byt’ aj osobnost’ navrhovaného prekladatel’a - Šrobár odporučil Ivana Kraska, ktorý v tomto období nakrátko pôsobil vo funkcii intendanta SND. S jeho vol'bou autor súhlasil aj preto, že s Kraskom boli spoločne členmi Umeleckej besedy slovenskej.

Konflikt Jeřábka a Mathesia o právomoci v ekonomických a umeleckých otázkach rozdelil na dva tábory nielen činoherný súbor, ale aj kultúrnu verejnosț. V rámci nich sa Wollman priklonil na stranu svojho kolegu a priatel’a z Koliby Mathesia, ktorý žiadal rozšírenie česko-slovenskej divadelnej sezóny na úkor nemeckého a mad’arského repertoáru. ${ }^{19}$ Podla vyjadrenia Wollmana prekážala slovenským autonomistickým kruhom aj silná idea "čechoslováctví" Rastislava, ktorý „reflektuje v této době onen spor náboženství a vlády chtivosti známý již z Bohokrále“. ${ }^{20} \mathrm{Z}$ týchto dôvodov sa autor rozhodol v máji 1921 odvolat’ svoj súhlas s Kraskovým prekladom. Nakoniec mala byt premiéra Rastislava, "novej slovenskej tragédie“ (tak ho v repertoárovom pláne propagovalo vedenie SND), odložená na jeseň, aby bolo možné pripravit lepšiu scénickú výpravu, a v dramaturgickom pláne sa neustále odsúvala. Autor musel dokonca intervenovat’ za jej realizáciu. ${ }^{21}$

Za scénické uvedenie Rastislava sa nakoniec postavil v októbri 1921 Šrobár a pre slovenský preklad odporučil inú známu osobnost’ - Hanu Gregorovú, spisovatel'ku, manželku Jozefa Gregora Tajovského. Ale so samotnou prípravou hry (skúšky, scéna, réžia) nebol Wollman spokojný. Svobodovo režijné poňatie, ktoré vychádzalo z tradície kvapilovského impresionizmu a realistickej drobnokresby, sa zakladalo na celkovom psychologickom preniknutí do dobovej atmosféry a na vyzdvihnutí kulti-

${ }^{17}$ F. Wollman v liste E. Pacovskému zo 17. 8. 1920, ktorý je uložený v LA PNP v Prahe, fond Emil Pacovský.

${ }^{18}$ F. Wollman v liste A. Pražákovi [nedatované, pravdepodobne začiatok pät’desiatych rokov], ktorý je uložený v LA PNP v Prahe, fond Albert Pražák.

${ }^{19}$ LAJCHA, L. Zápas o zmysel a podobu SND 1920 - 1938. Dokumenty 1. Bratislava : Divadelný ústav, 2000, s. 18.

${ }^{20}$ F. Wollman v liste E. Pacovskému z 24. 10. 1921, ktorý je uložený v LA PNP v Prahe, fond Emil Pacovský.

${ }^{21}$ Porov. F. Wollman v listoch M. Svobodovi zo 14. 12. 1921 a 19. 12. 1921, ktoré sú uložené v LA SNK v Martine, č. sign. 191 B 26. 
vovaného hlasového a pohybového prejavu hercov. Podla autora bol inscenačný štýl Rastislava zastaralý, málo dramatický a nezodpovedal princípom modernej expresionistickej poetiky. No aj napriek tomu, že inscenácia mala určité nedostatky, znamenala premiéra Rastislava v tretej sezóne SND d’alšie potvrdenie postupnej slovakizácie činoherného repertoáru. Práve Rastislav bol v roku 1922 pohostinsky uvedený aj na východnom Slovensku. 22

Pre zaujímavost' môžeme uviest', že v hre Rastislav vystupovala L'udmila Šimonovičová, ktorá sa neskôr stala známou spisovatel'kou píšucou pod pseudonymom Zuzka Zguriška. Jej účinkovanie v jednej z hlavných postáv - pohanskej kňažky Marvy, ktorú alternovala s Hedou Klokotskou - zožalo úspech nielen u obecenstva, ktoré jej venovalo vel'ký potlesk po každom dejstve, ale ocenila ho aj divadelná kritika. Vyzdvihla „vyvinutý zmysel pre jemné odtieňovanie a farebnost’ slova“23, najmä zdržanlivú gestikuláciu, dramatické vcítenie sa do úlohy, emotívnu recitáciu a deklamačnú presnost'. No jej kariéra herečky sa nenaplnila. Zo spomienok Strminou liet (1972) sa dozvedáme, že ju znemožnila choroba hlasiviek, čo prispelo aj k jej neskoršej orientácii na spisovatel'skú dráhu. Úspech Rastislava pri jeho prvom uvedení (od premiéry v marci 1922 sa hral šestkrát) priviedol autora $\mathrm{k}$ myšlienke začlenit drámu (po úprave) do historickej trilógie Velká Morava $(1925)^{24}$, v ktorej by bola československá štátnost' ešte silnejšie spojená s cyrilometodským odkazom.

Wollman však nebol spokojný s reakciou bratislavskej divadelnej kritiky, ktorá podla jeho slov zámerne bojkotovala uvedenie inscenácie. Napríklad recenzent Slovenského denníka chápal Rastislava ako ideálnu látku pre historickú drámu, ale Wollmanov pokus o stvárnenie tejto tragickej osobnosti hodnotil ako „hlboký pád“ a „omyl“ ${ }^{\prime 25}$ Hre vyčítal schematickú kompozíciu, prvoplánovú didaktickost' historických obrazov, no najmä nevierohodnost’ postáv, u ktorých „kŕčovitá, akýmisi archaizmy zatažená mluva“ ${ }^{26}$ nahrádza dramatické dialógy. Aj autor recenzie v Slovenskej politike písal o „nedramatickosti“ a „"neživotnosti“ jednotlivých scén a postáv, ktoré sú iba nositel'mi historických ideí. Celkovo však „vlastenecky“ odporučil „všetkým uvedomelým Slovákom, aby si nedali ujst’ príležitost' spatrit kus svojich dejín vo forme tak krásnej a ušl'achtilej“ ${ }^{27}$ Recenzent Slovenských pohl'adov zase chápal túto hru ako „literárnu drámu“ odrážajúcu viac čitatel’ské než divácke potreby, pretože autor „,vedel síce vložit’ osobám do úst slová, ale nevložil do nich života“. ${ }^{28}$

$\mathrm{Z}$ nedostatočného úspechu Rastislava u bratislavského obecenstva obviňoval Wollman slovenskú kritiku. Práve preto sa asi mesiac po premiére rozhodol, že je potrebné, aby sa uskutočnila odborná reflexia a kritická analýza celkového stavu a skutočných úmyslov bratislavskej divadelnej publicistiky. Vo svojej polemike publiko-

${ }^{22}$ HIMIČ, P. Divadelný život Prešova. Od počiatkov do polovice 20. storočia. Bratislava : Divadelný ústav, 2014, s. 109.

${ }^{23}$ ZGURIŠKA, Z. Strminou liet. Bratislava : Slovenský spisovatel', 1972, s. 111.

${ }^{24}$ WOLLMAN, F. Velká Morava. Bratislava : Literárny odbor Umeleckej besedy slovenskej, 1924. [Historická trilógia (I. Mojmír, II. Rastislav, III. Svatopluk).] Ohlasy: KRECAR, J. České knihy. In Moderní revue, 1924 - 1925, roč. 31, sv. 40, č. 1, s. 18, 8. 10. 1924; PRAŽÁK, A. Velká Morava v slovenské literatuře. In Akademie, 1924 - 1925, roč. 28 , príloha Rudé květy 20 , č. 5, s. $34-40$.

${ }^{25}$ V. K. Rastislav. In Slovenský denník, 1922, roč. 5, č. 66, s. 4, 21. 31922.

${ }^{26}$ Tamže.

27 -k. Rastislav. In Slovenská politika, 1922, roč. 3, č. 67, s. 5, 22. 3. 1922.

${ }^{28}$ ČIETEK, J. [J. Smrek]. Z repertoáru Slovenského Národného Divadla. In Slovenské pohl’ady, 1922, roč. 38, č. 4, s. 248. 
vanej v pražskom týždenníku Jeviště nikoho konkrétne nemenoval, zameral sa najmä na nevzdelanost' divadelných žurnalistov, ktorí ignorovali základnú dramaturgickú literatúru a ktorým „schází odbornictví a smysl pro uměleckou odpovědnost“. ${ }^{29}$ Mladý autor sa v článku dovolával hodnotiacej kritiky, ktorá by bola najmä teoreticky poučená a pri analýze dramatickej fabuly, ideí, charakterov, recepčného ohlasu atd'. by bola schopná rozlíšit aj dramatický žáner a podl'a toho hru posudzovat. „Něco jiného je naturalisticko-sociální drama a symbolicko-ideové ${ }^{\prime 30}$, rozhorčeným tónom tvrdil Wollman, ktorý v závere článku zhrnul osud svojej historickej hry: „»Kritické« pamflety nedouků o »Rastislavovi« ukončují důstojně celý onen půldruhého roku trvající proces, kterým dostal se kus na scénu. “31

Nasledujúce Wollmanove hry - expresionistická satira v troch dejstvách Člun na moři ${ }^{32}$ a ním upravená jednoaktovka Juliusa Zeyera Stará hádanka ${ }^{33}$ - mali spoločnú bratislavskú premiéru v SND 25. 1.1924 (réžia Vladimír Šimáček). ${ }^{34}$ Samotná hra aj zeyerovská dramatizácia dosiahli u bratislavských divákov iba menší úspech. ${ }^{35} \mathrm{Au}$ tor pôvodne počítal s uvedením Člunu na moři v pražskom avantgardnom kabarete Červená sedma, ktorý bol žánrovým predchodcom divadla malých foriem. ${ }^{36}$ Červená sedma však v roku 1922 z finančných dôvodov zanikla, a preto začal Wollman rokovat’ so Švandovým divadlom v Prahe.

Trojaktová hra Člun na moři s podtitulom „lidská groteska a politická utopie“ predstavovala na začiatku dvadsiatych rokov Wollmanov esteticky najhodnotnejší a ideovo najoriginálnejší dramatický text, v ktorom sa autor inšpiroval stroskotaním lode Titanic v roku 1912. ${ }^{37}$ Ide o expresionistickú grotesku oscilujúcu medzi sociálnou utópiou a alegorickým vyznením, čo je určené už základnou situáciou - uprostred oceánu sa na záchrannom člne plavia štyri osoby zo stroskotaného zámorského parníka Siegfried, ktorý smeroval do Ameriky. Kompozične prepracovaná hra mala divákov udržiavat’ v napätí psychologicky prepracovanou atmosférou a vyhrotenými dialógmi. Jej dej je preto lokalizovaný do obdobia pred fiktívnou druhou svetovou vojnou a alegoricky symbolizuje blížiacu sa katastrofu a možný koniec l’udskej civilizácie. Analogicky bezvýchodiskové je aj postavenie štyroch stroskotancov, ktorí očakávajú na šírom mori smrt’. Ideový význam Člunu na moři vyplýva najmä z dialógov postáv, ktoré typovo zastupujú protikladné svety. Ide o l'avicového agitátora Prehnala (je to nemanželský syn židovského bankára z Viedne a slovenskej slúžky) a kapitalistu, miliardára Johna Smitha, d’alej tu vystupuje Smithova mladá aristokra-

${ }^{29}$ WOLLMAN, F. Poznámky k bratislavské kritice »Rastislava«. In Jeviště, 1922, roč. 3, č. 15, s. 224.

${ }^{30}$ Tamže.

${ }^{31}$ Tamže.

32 Knižné vydanie: WOLLMAN, F. Člun na moři. Praha : F. Švejda, 1923. Inscenácie: Švandovo divadlo v Prahe, premiéra 17. 1. 1923, režisér Jan Bor; SND, premiéra 25. 1. 1924; Zemské divadlo v Brne, premiéra 26. 11. 1934, réžia Ctirad Sonevend. Avízo o naštudovaní hry bolo uvedené v programe Národného divadla v L'ubl'ane na rok 1926, ale sa nerealizovalo.

${ }^{33}$ Knižné vydanie: WOLLMAN, F. Stará hádanka. Bratislava : vl. n., 1923.

${ }^{34}$ Ohlasy: bh [B. Haluzický]. Z bratislavské činohry. In Lidové noviny, 1924, roč. 32, č. 49, s. 7, 27. 1. 1924; -Jé-. K dnešnej premiére Wollmanových hier. In Slovenský denník, 1924, roč. 7, s. 5 - 6, 25. 1. 1924.

${ }^{35}$ Podrobná analýza deja je podaná v štúdii ZELENKOVÁ, A. Satirická groteska českej expresionistickej dramatiky (k interpretácii hry Franka Wollmana Člun na moři). In Slavica litteraria, 2015, roč. 18, č. 2, s. $81-90$.

${ }^{36}$ Porov. list F. Wollmana M. Svobodovi zo 14. 12. 1921, ktorý je uložený v LA SNK v Martine, č. sign. 191 B 26.

${ }^{37}$ Porov. -ný [J. Černý]. Frank Wollman. (5. 5. 1888 - 9. 5. 1969). In Český lid, 1969, roč. 56, č. 6, s. 348. 
tická manželka Liliana a ich čínsky sluha Ting-Tong. Každá z postáv cestovala do Ameriky s iným zámerom. Napr. agitátor chcel šírit’ revolúciu a zničit’ vojnový militarizmus, kapitalista - zbrojársky magnát zase zväčšit svoj oceliarsky trust a pokračovat' v rozširovaní zbrojenia. Metaforou, prostredníctvom ktorej sa odohrával boj životných vízií, nadnesene dokonca boj o osud l’udstva, bol spor o jedlo. Postavy, ktoré medzi sebou na začiatku zápasili o obmedzené zásoby potravín, prešli od prvotného sebectva až k vzájomným vražedným útokom, aby nakoniec skončili v depresiách či ako sebevrahovia. Miliardár v šialenstve zahodí vak s jedlom do mora a v bolestných kŕčoch zomiera, proletár v lútosti nad mŕtvou aristokratkou má v novej vízii výčitky svedomia a po strate všetkých ideálov i nádejí si radšej volí dobrovolnú smrt̉ skokom do mora. Nažive zostáva iba čínsky sluha, ktorému bol stret kapitálu s revolučnou ideou úplne lahostajný - pri existenčných hádkach nedbalo prežúval ryžu a fatalisticky vyčkával koniec.

Wollmanova satirická groteska, v ktorej sa odrazili myšlienky sociálneho humanizmu a utopického socializmu, symbolizovala formou alegórie skazu l'udstva v budúcej svetovej vojne a otázku úlohy osobnosti v dejinách. Konflikt l’avicových ideí a kapitalizmu bol exponovaný do východiskovej dramatickej situácie obmedzeného priestoru $\mathrm{v}$ malom osamotenom člne na mori. Utopická socialistická myšlienka sa odrazila najmä v postave l’avicového agitátora, ktorý ponúkne svoje zásoby jedla pod podmienkou, že bankár využije svoj vplyv a kapitál na zastavenie vojny a presadenie globálneho mieru. Nie náhodou tento motív neskôr pripomínal divadelným kritikom postavu doktora Galéna z hry Karla Čapka Biela nemoc (1937)..$^{38}$ Ale Wollmanov agitátor, ktorý sa usiluje získat od bankára výmenou za jedlo plány zbrojárskych firiem, nemá také pacifisticky ušlachtilé úmysly, ako ich má Čapkova postava. Jeho zámerom bolo vyzbrojit’ chudobné a sociálne ponížené vrstvy a burcovat' ich k násilnej vzbure. Krátko pred smrtou však dospeje k otrasnému sebapoznaniu, ktoré demaskuje komunistické vízie o dosiahnutí spravodlivej spoločnosti cestou revolučného násilia: „Chtěl jsem pomoci bídným a utlačeným! (...) Byl bych lepší než tito, kdybych se byl narodil na trůnu anebo v bohatství? Co je moc? “39

Realisticko-expresionistická poetika mladého autora vyvolávala záujem kritiky a najmä očakávanie ideovej drámy. Ako konštatoval konzervatívny dramatik Jaroslav Hilbert, hra „mladého začátečníka“, ktorá nepracuje so symbolmi, vnáša do domáceho repertoáru „,nové tóny“ v exponovaní dramatických, existenciálne ladených konfliktov, ako sú žiarlivost', nenávist', balancovanie na hrane života a smrti, zobrazenie l’udských vášní a nízkych pudov. „Je to její originalita a je to její hloubka (...) na jejího mladého autora dáme si nyní, kdy jsme ho poznali, bedlivý pozor. " ${ }^{40}$ Wollman totiž v hre uplatnil zásady dramatického javiskového expresionizmu, ktoré presadzoval napr. režisér a šéf činohry pražského Národného divadla Karel Hugo Hilar, experimentujúci so zvukovými, vizuálnymi a scénickými efektmi. Na expresionistický charakter Wollmanových postáv poukazovalo ich kolektivistické poňatie, ktoré sa odrazilo v konfrontácii rôznych dramatických typov. Ako uvádza divadelný historik František Černý, expresionistická postava mala byt’ predovšetkým pesimistickým

\footnotetext{
${ }^{38}$ Tamže.

${ }^{39}$ WOLLMAN, F. Člun na moři. Praha : nakl. František Švejda, 1923, s. 38.

${ }^{40}$ J. H. [J. Hilbert]. Divadlo. Komorní hry na Smíchově. In Venkov, 1923, roč. 18, č. 14, s. 4, 19. 1. 1923.
} 
svedectvom o človeku v hraničnej situácii. ${ }^{41}$ Divadelný teoretik Ivo Osolsobě s odstupom času síce vel'mi stručne, ale výstižne charakterizoval Člun na moři ako „konflikt spoločenských typov v existenciálnych hraničných situáciách“42.

Českí kritici mali pri pražskej premiére k hre výhrady, ale vyzdvihli jej dramatickost', pokus o stvárnenie všel’udskej problematiky a objektívneho charakteru postáv. Aj v bratislavskom prostredí si dielo získalo zaslúženú pozornost'. Wollman v tejto súvislosti napísal priatelovi, kultúrnemu historikovi Čeňkovi Zíbrtovi, že hra „spatřila světlo rampy slovenské $\mathrm{k}$ všeobecné spokojenosti“43. V recenzii publikovanej v Slovenskom denníku je uvedené, že Člun na moři, ktorý „je najvýznačnejším dramatom poslednej doby“, bol predtým v Švandovom divadle na Smíchove inscenovaný „S úspechom skutočne prenikavým“ ${ }^{44}$ SND s touto inscenáciou hostovalo v Košiciach (8. 4. 1924). Nepodpísaný recenzent zo Slovenského východu považoval hru, ktorá pravdepodobne dosiahla iba slabší úspech pred poloprázdnym hladiskom, za neobvyklé spojenie "l’udskej grotesky“ a "politickej utopie“, pričom vynikol najmä Andrej Bagar v postave čínskeho sluhu. ${ }^{45}$

Člun na moři poukazoval na vysoké, aj ked' zatial' nenaplnené nádeje mladého dramatika, odporúčaného bratislavskému obecenstvu ako „domáceho“ autora, „ktorý pracuje a žije v jeho strede ${ }^{\prime 4}{ }^{6}$ Hru vyzdvihla najmä Hana Gregorová v Robotníckych novinách, charakterizujúca Wollmana ako bratislavského autora, „mena vážneho v literárnom i spoločenskom živote ${ }^{447}$, a slovenskému divákovi objasňovala ideu hry, ktorá symbolizovala zápas jednotlivých tried a rás o nadvládu nad svetom. Podla nej však dramaticky účinné scény a hlboké Wollmanove myšlienky oslabila nezvládnutá príprava inscenácie. Kritizovala nedostatočný počet skúšok a celkové režijné poňatie, ktoré neodrážalo úplne autorov zámer, a tým ani nedovol'ovalo hercom naplno rozvinút ich talent. K podobnému záveru dospel aj autor recenzie v Slovenskom denníku. Dramaticky účinné postavy - symboly - spája túžba po spasení a po novom človeku, ktorým sa však fanatický agitátor, nepoznajúci lásku ani radost̉ zo života, nestáva. Nádej na budúcnost̉ tak má iba chudobný sluha - Číňan, ktorému sú vzdialené akékolvek ideológie. Tým Wollman podl’a názoru autora článku ukázal divákom „nový typ človeka (...) milujúceho život" ${ }^{\prime 48}$. Recenzent charakterizoval Wollmanovu drámu ako „zvláštnu, novú, neobvyklú“, s vyspelou divadelnou technikou a pôvodnou javiskovou „rečou“. Vyzdvihol autorovu schopnosț experimentu, ktorý je „originálny nielen v celom sujetu hry, ale i v celom prevedení" ${ }^{49}$

Aj napriek kladnému hodnoteniu Člunu na moři pripisoval autor vinu za celkový neúspech svojej dramatickej tvorby prežívajúcemu ochotníctvu v činohernom súbore SND a nepripravenosti domáceho obyvatel'stva, zaostávajúceho za divákmi mad’arskej, nemeckej či českej národnosti. V prednáške Poprevratová slovenská dráma, ktorú

${ }^{41}$ ČERNÝ, F. Kapitoly z dějin českého divadla. Praha : Academia, 2000, s. 287.

${ }^{42}$ OSOLSOBĚ, I. Danost tvarově intencionální aneb wollmanovské opáčko. In Program Státního divadla v Brně, s. 15.

${ }^{43}$ F. Wollman v liste Č. Zíbrtovi z 5. 2. 1924, ktorý je uložený v LA PNP v Prahe, fond Čeněk Zíbrt.

${ }^{44}$-Jé-. K dnešnej premiére Wollmanových hier. In Slovenský denník, 1924, roč. 7, s. 5, 25. 1. 1924.

${ }^{45}$ Člun na moři. In Slovenský východ, 1924, roč. 7, č. 84, s. 4, 10. 4. 1924.

46 -Jé-. K dnešnej premiére Wollmanových hier.

${ }^{47}$ H.G. [H. Gregorová]. „Čln na mori“. In Robotnícke noviny, 1924, roč. 21, č. 26, s. 5, 31. 1. 1924.

${ }^{48}$-Jé-. Frank Wollman: "Čln na mori“ a "Stará hádanka“. In Slovenský denník, 1924, roč. 7, č. 23a, s. 6, 27. 1. 1924.

${ }^{49}$ Tamže. 
predniesol 9. 1. 1928 v cykle Umeleckej besedy o slovenskom povojnovom umení, označil SND za „svetovú raritu“, pretože vzniklo politicky po roku 1918, ked’ údajne neexistovala pôvodná slovenská dráma a ani slovenský profesionálny herecký súbor. Literárny kritik Andrej Mráz nadviazal na Wollmana referátom o súčasnom románe a tiež vo svojej anotácii publikovanej v Slovenskom denníku ${ }^{50}$, pričom zachytil niektoré jeho myšlienky. Wollman sa totiž rozhodol referát - pravdepodobne pre búrlivú odozvu u poslucháčov - nepublikovat. Podl'a Mráza dospel Wollman vo svojej prednáške k záveru, že buditel'ský charakter slovenského divadla prežíval aj po roku 1918 v nových spoločenských pomeroch, ktoré si už vyžadovali vyššiu umeleckú kvalitu.

Slovenské divadelníctvo Wollman porovnával aj s dramatickou činnostou ostatných malých slovanských národov. Podl’a neho slovenská mentalita vykazuje nedostatočné porozumenie pre skutočnú dramatickost’ a $\mathrm{z}$ tohto dôvodu absentujú tragédie či činoherné vážne kusy zo súčasnosti. Naopak, najlepšie je vraj „domáce psyché“ pre satirickú veselohru, pričom v dramaturgickom pláne by sa mal ako určitý inšpiračný zdroj viac zohl'adnit hodnotný slovanský repertoár a najmä juhoslovanská dramatika s jej rozvinutou činohernou tradíciou. Dejiny slovenskej činohry sú podla neho celkovo viac sociologicko-politickým problémom než estetickou záležitostou - chýba objektívny odstup, dramaturgické plány, režiséri zatial' iba vyrastajú, obecenstvo treba vychovat'. Vybudovanie moderného slovenského divadla musí byt spoločnou záležitost’ou všetkých demokratických zložiek domácej spoločnosti, ktorá by nemala kopírovať české divadlo z pozícií čechoslovakizmu.

Dramatické texty Franka Wollmana (javiskovo realizované aj nerealizované, ktoré sa nachádzajú v pozostalosti) celkovo odrážajú svár jeho osobnosti a exponujú vel'ké, nosné idey, na pozadí ktorých sa odohráva zložitý boj o duchovné hodnoty. Väčšinou ide o rukopisy drám zo štyridsiatych a pätdesiatych rokov, prezentujúce prostredníctvom aktualizovanej historickej látky z českých a európskych dejín existenciálny konflikt medzi dobrom a zlom alebo medzi indivíduom a kolektívom (Stavitel a d'ábel, Poslední masopust Petra Voka na Krumlově, Svatba v Káni predměstské atd’.). Medzi nimi vyniká najmä dramatická baladická kronika Fridland, napísaná v protektorátnom období v rokoch 1941 - 1944, ktorá sa pokúsila v českej kultúrnej tradícii rehabilitovat' osobnost’ rozporuplného vojvodcu Albrechta z Valdštejna (1583 - 1634). Úsilie predstavit’ na domácom javisku nový žáner na rozhraní klasickej drámy a slovesnej literatúry (súčastou textu sa stal úvod aj doslov v podobe vedeckého traktátu) však po februári 1948 nemalo šancu na scénickú realizáciu. ${ }^{51}$

Pre všetky Wollmanove dramatické diela, a to bez ohl'adu na dobu ich vzniku, je charakteristická preexponovaná zataženost̉ textu dokumentárnymi informáciami a „nedramatickými“ detailmi, ktoré majú silný sklon k didaktickosti a tézovitosti. Autorova inklinácia ku knižnej dráme prináša až kronikársku popisnost', zal’udnenie hry neobvykle vel'kým množstvom schematických postáv, ktoré namiesto rýchleho spádu dialogických replík alebo dejovej akcie ilustratívne potvrdzujú v archaizujúcich a vel'kolepých prehovoroch celkovú koncepciu drámy. V konfliktoch postáv sa odráža najmä psychologický aspekt - strety nevyplývajú iba z individuálnych po-

${ }^{50}$ Nepodpísané [A. Mráz]. Slovenské poprevratové drama. In Slovenský denník, 1928, roč. 11, č. 9a, s. 3, 12. 1.1928.

${ }^{51}$ Porov. ZELENKOVÁ, A. Wollmanova dráma Fridland. Ideologické polemiky o dramatickom stvárnení valdštejnskej tematiky. In Časopis Matice moravské, 2016, roč. 135, č. 2, s. 315 - 333. 
hnútok, ale odrážajú určitý mravný étos, dobovú konkretizáciu sociálnych a etických tém. Literárny historik Antonín Grund v medailóne z roku $1948^{52}$ hodnotil Wollmana ako dramatika intelektuálneho typu, ktorý akcentovaním metafyzických mravných hodnôt a ich vzájomnej konfrontácie (tragickost’ a vznešenost', láska a smútok, viera a rozum, jedinec a kolektív atd'.) kládol na príjemcu maximálne recepčné nároky, ktoré však nevyplývali z akejsi „profesorskej učenosti“, ale z dramatického exponovania ideových problémov do štruktúry hry. Podl’a Grunda je snaha o tragický konflikt u Wollmana spojená aj s hl'adaním adekvátneho tvaru, ked' sa musí vyvarovat’ režisérskych avantgardných experimentov, vychádzajúcich v ústrety „zhýčkanému“ obecenstvu. Autor preto stelesňuje dramatika „iluse, ale silného sociálního pathosu (...) lyrické něhy a mravního ethosu“53. Podobne hodnotil Wollmana aj jeho doktorand a neskorší spolutvorca nitrianskej semioticko-komunikačnej školy Anton Popovič. Dramatika charakterizoval ako racionálny typ, ktorý „mnoho vie, ale ešte viac požaduje od obecenstva". ${ }^{4}$

Ivo Osolsobě vyzdvihol iný aspekt dramatikovho umeleckého zamerania - určitý „,nonkonformizmus“55. V dvadsiatych rokoch 20. storočia, v období vlny záujmu o Paríž, hl'adal Wollman východiská v literárnom výskume slovanského Balkánu, ktorého popredných dramatikov Iva Vojnovića (1857 - 1929) a Ivana Cankara (1876 - 1918) začleňoval do svetovej literatúry. ${ }^{56}$ Wollmanov bádatel’ský záujem o juhoslovanskú expresionistickú dramatiku sa zákonite musel odrazit’ vo vedomom smerovaní k výrazovým prostriedkom expresionizmu, akými sú napríklad sociálny utopizmus, drastickost’ scén a citová exaltácia postáv. Preto je prekvapujúce, že autorova dramatická poetika nebýva zarad’ovaná do expresionistického prúdu brnianskej Literárnej skupiny a jej teoretika Františka Götza, ani nie je spomínaná v súvislosti so slovenským expresionizmom, ktorý sa prejavil na scéne SND v rokoch 1920 - 1925, napr. v dielach Jána Poničana, Štefana Letza, Andreja Siráckeho, Jarka Elena atd. ${ }^{57}$ Vo Wollmanovom prípade nejde o absolútny rozklad realistickej poetiky, ale najmä o jej transformáciu do nového typu dramatického textu, ktorý nemá byṫ záznamom vonkajšej skutočnosti, ale umením šokujúceho výrazu. Z autorových hier sa Člun na moři približuje najviac k revolučnému expresionizmu, ktorý problém jedinca a spoločnosti rieši ako filozofický problém spätý s postulovanými ideami súdržnosti, humanistickej l’udskosti a kolektivistického cítenia. Wollmanove postavy končia v nihilizme a pasivite, pretože dominujúca dezintegrácia subjektu stále signalizuje konflikt so

${ }^{52}$ GRUND, A. Osobnost Franka Wollmana. In Pocta Fr. Trávníčkovi a F. Wollmanovi. (Eds. A. Grund A. Kellner - J. Kurz). Brno : Slovanský semináŕ Masarykovy univerzity, 1948, s. 39 - 53.

${ }^{53}$ Tamže, s. 52.

${ }^{54}$ POPOVIČ, A. Umenie a veda v diele Franka Wollmana. In Slovenské divadlo, 1963, roč. 11, č. 3, s. 452.

${ }^{55}$ OSOLSOBĚ, I. Danost tvarově intencionální aneb Wollmanovské opáčko. In Program Státního divadla v Brně, s. 14.

56 F. Wollman sa systematicky venoval teatrologickému výskumu juhoslovanskej drámy a jej prínosu do európskeho kontextu (Srbochorvatské drama, 1924; Slovinské drama, 1925; Bulharské drama, 1928; Dramatika slovanského jihu, 1930). Tento „vklad“ velakrát komparoval vo svojich monografiách a recenziách s možnost’ami dramaturgickej situácie v slovenskom divadelníctve.

${ }^{57}$ Porov. PAŠTEKA, J. Po stopách expresionizmu v slovenskej dramatike (Pohl’ady do tvorby dvadsiatych rokov). In Slovenské divadlo, 1995, roč. 43, č. 1, s. 3 -15; PAŠTEKA, J. Po stopách expresionizmu v slovenskej dramatike - II. Pohlady do tvorby dvadsiatych rokov. In Slovenské divadlo, 1995, roč. 43, č. 2, s. 114 - 134; PAŠTEKA, J. Po stopách expresionizmu v slovenskej dramatike - III. Pohl'ady do tvorby dvadsiatych rokov. In Slovenské divadlo, 1995, roč. 43, č. 3, s. $240-248$. 
svetom, s predstavou jeho lepšej podoby. Je tu aj blízkost’ s eschatologickým variantom slovenskej expresionistickej drámy. Vnútorná opozícia subjektu ako dištinktívne kritérium slovenskej expresionistickej drámy sa u Wollmana prejavuje aj tým, že v prípade civilizačného kolapsu myslia jeho protagonisti pudovo, t. j. sústredia sa na vlastné prežitie, na zachovanie existencie seba ako jedinca. ${ }^{58} \mathrm{~V}$ Člune na moři je paradox mravnosti „vykreslený ako kolaps a nasledovné rúcanie mravných noriem súčasne so zákonmi spoločnosti $(. . .)^{\text {‘59}}$.

Wollmanov expresionizmus je výrazne podfarbený prvkami idealistického humanizmu a najmä sociálnym reformizmom. Jeho postavy intenzívne prežívajú vnútorný svár dobra a zla, pocity psychologicky rozpolteného jedinca, ktorý chce vytvorit’ nový, utopický svet, a nachádzajú umelecký výraz v dramaticky exponovaných ideách s nadosobnou symbolickou platnostou. Miestne a časové určenie medzi polaritou západnej a východnej civilizácie, svorník medzi minulostou a budúcnostou rozohráva zdanlivo epický príbeh, v ktorom hyperbolizované postavy túžia po vel'kom revolučnom čine. Autorov dramatický text preto nemá podobu reálno-dramatického dialogického „obrazu“ či výjavu, ale podobu určitého knižného libreta so štylizovaným a abstraktným jazykom, ktorý poukazuje na symbolistické korene z prelomu 19. a 20. storočia. Určité Wollmanove vedecké východiská a nedramatické chápanie textovej, v podstate slovesnej štruktúry jeho hier charakterizoval v roku 1934 bývalý člen expresionistickej Literárnej skupiny Čestmír Jeřábek. Autor podl’a neho „není (...) tím, čemu říkáme rozený dramatik, dramatik krví a osudem “60. Wollmanove drámy majú výrazný slovesný základ, pretože jednotlivé akcie, postavy a dejové zápletky sú poňaté ako čisto literárne znaky, ktoré nie sú transformované do inscenačnej, divadelnej roviny. ${ }^{61}$

Aj ked’ sa Wollmanove hry nakoniec nestali súčastou kmeňového repertoáru SND a v súčasnosti už upadli do zabudnutia, predsa len zostávajú svedectvom dobového hladania vtedajšej dramatiky, ktorá sa pod vplyvnom tragických vojnových zážitkov snažila o nový umelecký tvar zachytávajúci vel'ké kolektivistické hnutia, v ktorých sa jedinec stáva nositel'om nadosobného ideálu. Prechod od symbolistickej abstraktnosti a psychologizmu k expresionistickému vizionárstvu a hyperbolickému obrazu vel'kých sociálnych konfliktov zasahuje aj dramatickú tvorbu Franka Wollmana v dvadsiatych rokoch 20. storočia. Tá vyjadruje povojnové idey reagujúce na spoločenské a morálne otrasy, na konflikt medzi revolučným zástupom a silným indivíduom, ktorý sa odrazil najmä v najlepšej Wollmanovej hre Člun na moři. Práve táto sociálna utópia a politická groteska za určitých okolností - napr. po dôkladnej dramaturgickej revízii - môže predstavovat’ oživenú estetickú hodnotu, ktorá bude otvorená pre d’alšie interpretácie.

${ }^{58}$ Porov. JENČÍKOVÁ, M. Dištinkcie slovenskej expresionistickej drámy rokov 1920 - 1925. Skica k typológii. In Slovenské divadlo, 1997, roč. 45, č. 2 -3, s. $140-150$.

59 Tamže, s. 142.

${ }^{60}$ Č.J. [Č. Jeřábek]. Z brněnské činohry. In Lidové noviny, 1934, roč. 42, č. 599, s. 9, 28. 11. 1934.

${ }^{61}$ MISTRÍK, M. K problematike divadelného znaku. In Slovenské divadlo, 1992, roč. 40, č. 1, s. 31. 


\section{FRANK WOLLMAN'S PLAYS STAGED BY THE SLOVAK NATIONAL THEATRE IN THE 1920s}

\section{Anna ZELENKOVÁ}

Using new archival material, the study explores Frank Wollman's plays staged by the Slovak National Theatre in Bratislava in the 1920s. Recognised as a Czech expert in Slavonic studies, he lectured at the Faculty of Arts of Comenius University in Bratislava. In the early years of his professional career, he presented himself as a "manifestly Czechoslovak" dramatist, whose drama Bohokrál (1921) [The Godking] published in book form portrayed Alexander the Great. The ideas of Czech and Slovak togetherness were conveyed through the Great Moravia theme in his historical tragedy Rastislav (1922). His Člun na moři (1924) [A Boat at Sea], a "human grotesque and political utopia" juxtaposing opposing human types, got a particularly keen public response. Overall, Wollman's dramas reflected on major social conflicts, and by putting emphasis on moral ethos, they were intellectual in nature. They linked expressionist elements with the tradition of classical realistic drama. Even though the plays were not included in the basic repertory of the Slovak National Theatre when first staged, they have remained a witness of the author's artistic formation as well as of the dramaturgy of SND.

\section{LITERATÚRA}

A.P. [PROCHÁZKA, Arnošt]. Nové publikace. In Moderní revue, 1921 - 1922, roč. 28, sv. 37, č. 10 -11-12, s. $312-325,8.7 .1922$.

bh [HALUZICKÝ, Bohumil]. Z bratislavské činohry. In Lidové noviny, 1922, roč. 30, č. 142, s. 7, 19. 3. 1922.

ČAVOJSKÝ, Ladislav. Činoherné umenie v desatročí 1938 - 1948. In MISTRÍK, M. a kol. Slovenské divadlo v 20. storočí. Bratislava: Veda, 1999, s. 128 - 149. ISBN 8022405779.

ČERNÝ, František. Kapitoly z dějin českého divadla. Praha : Academia, 2000. 410 s. ISBN 80-2000780-2.

F. S. [SEKANINA, František]. [Bez názvu]. In Právo lidu, 1922, roč. 31, č. 188, s. 11, 13. 8. 1922.

HIMIČ, Peter. Divadelný život Prešova. Od počiatkov do polovice 20. storočia. Bratislava : Divadelný ústav, 2014. 283 s. ISBN 9788089369775.

JENČÍKOVÁ, Mária. Dištinkcie slovenskej expresionistickej drámy rokov 1920 - 1925. Skica k typológii. In Slovenské divadlo, 1997, roč. 45, č. 2 -3, s. 140 - 150. ISSN 0037-699X.

LAJCHA, Ladislav. Prvých dvanást’ sezón. Predpoklady vzniku činohry SND: 1920 - 1932. In Slovenské divadlo, 1994, roč. 42, č. 3, s. 246 - 261. ISSN 0037-699X.

LAJCHA, Ladislav. Zápas o zmysel a podobu SND (1920 - 1945). Dokumenty 1. Bratislava : Divadelný ústav, 2000. 1003 s. ISBN 80-88987-16-4.

LUTHER, Daniel. Česi v Bratislave 1919 - 1945: adaptácia a marginalizácia. In Slovenský národopis, 2013, roč. 61, č. 4, s. 368 - 378. ISSN 1335-1303.

MISTRÍK, Miloš. K problematike divadelného znaku. In Slovenské divadlo, 1992, roč. 40, č. 1, s. 29 - 33. ISSN 0037-699X.

MISTRÍK, Miloš a kol. Slovenské divadlo v 20. storočí. Bratislava : Veda, 1999. 539 s. ISBN 8022405779.

MLYNÁRIK, Ján. Českí profesori na Slovensku I. Českí profesori a ich slovenskí žiaci na Univerzite Komenského v rokoch 1919 - 1949. Praha : Danubius, 1994. 266 s. ISBN 80-901768-3-6. 
OSOLSOBĚ, Ivo. Danost tvarově intencionální aneb wollmanovské opáčko. In Program Státního divadla v Brně, 1968, roč. 39, máj, s. 13.

PAŠTEKA, Július. Po stopách expresionizmu v slovenskej dramatike (Pohl'ady do tvorby dvadsiatych rokov). In Slovenské divadlo, 1995, roč. 43, č. 1, s. 3 - 15. ISSN 0037-699X.

PAŠTEKA, Július. Po stopách expresionizmu v slovenskej dramatike - II. In Slovenské divadlo, 1995, č. 2, s. $114-134$. ISSN 0037-699X.

PAŠTEKA, Július. Po stopách expresionizmu v slovenskej dramatike - III. In Slovenské divadlo, 1995 ,č. 3, s. 240 - 248. ISSN 0037-699X.

PRAŽÁK, Albert. Velká Morava v slovenské literatuře. In Akademie, 1924 - 1925, roč. 28, př́loha Rudé květy 20, č. 5, s. $34-40$.

RYCHLÍK, Jan. Češi na Slovensku v letech 1918 - 1938. In Česi na Slovensku. (Ed. Hana Zelinová). Martin : Slovenské národné múzeum, 2000, s. 5 - 17. ISBN 80-8060-058-9.

št. [ŠTEKOVSKÝ, Bohuslav]. Původní drama na slovenském Národním divadle. In Lidové noviny, 1921, roč. 29, č. 64, s. 9, 6. 2. 1921.

ŠTEFKO, Vladimír a kol. Dejiny slovenskej drámy 20. storočia. Bratislava : Divadelný ústav, 2011. 816 s. ISBN 9788089369362.

ŠTEFKO, Vladimír a kol. Dejiny slovenského divadla I. Bratislava : Divadelný ústav, 2018. 731 s. ISBN 978-80-8190-039-6.

WOLLMAN, Frank. Bohokrál. Praha : Veraikon, 1921. 76 s.

WOLLMAN, Frank. Člun na moři. Praha : F. Švejda, 1923. 39 s.

WOLLMAN, Frank. Poznámky k bratislavské kritice Rastislava. In Jeviště, 1922, roč. 3, č. 15, s. $223-224,6.4 .1922$.

WOLLMAN, Frank. Rastislav. Košice : Slovenský knihtisk, 1922. 59 s.

WOLLMAN, Frank. Velká Morava. Bratislava : Literárny odbor Umeleckej besedy slovenskej, 1924. $94 \mathrm{~s}$.

ZELENKOVÁ, Anna. Bibliografia Franka Wollmana. In Slavista Frank Wollman v kontexte literatúry a folklóru I. (Eds. Hana Hlôšková - Anna Zelenková). Bratislava - Brno : Ústav etnológie SAV : Slavistická společnost Franka Wollmana v Brne, 2006. 76 s. ISBN 80-968971-6-0.

ZELENKOVÁ, Anna. Frank Wollman a Jozef Gregor Tajovský - dve osobnosti česko-slovenského kontextu v medzivojnovom období. In Středoevropský areál ve vnitřních souvislostech (česko-slovensko-mad'arské reflexe). (Eds. Ivo Pospíšil - Josef Šaur). Brno : Masarykova univerzita, 2010, s. 131 - 142. ISBN 978-80-210-5300-7.

ZELENKOVÁ, Anna. Wollmanova dráma Fridland. Ideologické polemiky o dramatickom stvárnení valdštejnskej tematiky. In Časopis Matice moravské, 2016, roč. 135, č. 2, s. 315 - 333. ISSN 0323-052X.

ZGURIŠKA, Zuzka. Strminou liet. Bratislava : Slovenský spisovatel', 1972. 270 s.

\section{Anna Zelenková}

Slovanský ústav AV ČR, v. v. i.

Valentinská 1

11000 Praha 1

Česká republika

e-mail: zelenkova.anna@centrum.cz 